\title{
Research on the Innovation of Modern Logistics Management Mode under the Environment of Electronic Commerce
}

\author{
Meng Wei ${ }^{a}$, Yingchun Wang ${ }^{b}$ \\ School of Management, Tianjin University of Technology, Tianjin 300384, China. \\ aweimeng245@163.com, btjycwang@gmail.com
}

\begin{abstract}
With the development of the world economy, people are increasingly high requirements of e-commerce and logistics management under the environment of e-commerce. logistics management innovation and need to modern logistics operation and management talents in this paper in view of the problems existing in the logistics management innovation, combined with current management mode of science, under the environment of e-commerce logistics management and logistics for in-depth study, in order to achieve the innovation of logistics management.
\end{abstract}

Keywords: Logistics, management mode, innovation.

\section{Introduction}

With the advent of the new economy, and e-commerce became a radical revolution in the field of business, brought earth-shaking changes to the traditional economic. trade negotiation can never leave home address on the Internet, but the deal eventually have to rely on in the background of logistics industry, the traditional way of transportation, warehousing in the new economy mode is undergoing a qualitative change. However, the logistics distribution has become an important restricting the development of China's e-commerce rapid "bottleneck", if there is no an effective, reasonable and smooth logistics system, electronic commerce has the advantage of it will be difficult to get effective play. Modern logistics management innovation enterprises, promote the development of e-commerce, is the important condition of market economy.

\section{Under the e-commerce environment logistics and distribution management}

Logistics management under the e-commerce environment, established in the electronic commerce model based on the use of its advantage of operating platform. rely on computer technology, make the enterprise of the whole production and sales in the process of an optimal operation and the innovation of logistics management under the e-commerce environment, need to change the traditional logistics theory, the information they need to make a substantial accumulation of related customer, through a series of data, on the premise of guarantee reasonable profits, make a guess in advance to purchasing to communicate effectively with production enterprise. obtain the relevant information, finally choosing your inventory and place, err on the side of the order plan and distribution and safe transport routes and automatic replenishment system, through the management of the logistics system. logistics distribution system of cost control management, information, tracking, and collect feedback information and so on, through to the inventory management, to optimize between inventory and service well, bring more profits to the enterprise. Through the management of distribution route, to accurately estimate the logistics and distribution of available resources, market positioning, to seek the most efficient logistics and distribution processes.

\section{Electronic commerce environment problems in logistics management}

\subsection{Harmony with the e-commerce logistics infrastructure backwardness}

Although in recent years, based on the logistics distribution mode of electronic commerce by the enterprises more and more attention in our country, our country in the transport, storage facilities, information and communication, packing and handling logistics infrastructure and equipment has a certain development, but overall, due to the idea, system and technology level, our country's logistics 
infrastructure is relatively backward, and all kinds of logistics infrastructure planning and construction of the lack of necessary coordination, poor compatibility and the sex of logistics infrastructure, lack of system functions, redundant construction, and the social demand gap is still large.

\subsection{Government under electronic commerce environment of logistics management is not perfect, lack of emphasis}

At present, the logistics management system is still in the region, department, division management, under the condition of the logistics industry involves the development of infrastructure, logistics technology and equipment, industrial policy, investment, finance, taxation and transportation standard, etc. belong to different functions of the government management. But insufficient understanding of modern logistics and various functional departments lack of unified coordination of strategic thinking, lack of coordination between regional unified planning and coordination and orderly development of synergy, to manage, has restricted the electronic commerce logistics distribution efficiency. Due to a lack of integration of logistics system, electronic commerce is very difficult to play its proper breakthrough empty asked, efficient trading function. In addition, the fiscal and taxation system adapted to e-commerce logistics distribution, social security system, market access and exit system, dispute resolution procedure is not perfect enough, such as defects and regulations system hindered the development of e-commerce logistics distribution.

\subsection{Familiar with short e-commerce logistics management talent}

Logistics development experience from abroad, the enterprise logistics management personnel shall have certain level of logistics knowledge and practical experience. Foreign logistics education and training is developed, to form the reasonable logistics talent education and training system. , by contrast, China's education is relatively backward in logistics talent, has yet to establish perfect logistics education system and personnel training system, and most of the transformation from traditional logistics enterprises and enterprises in terms of logistics management talent reserve and cultivate obviously can't adapt to the request of the era of electronic commerce, the electronic commerce knowledge and operation experience is insufficient, it directly affects the survival and development of the enterprise, has restricted the electronic commerce logistics distribution mode, also influence the success of e-commerce logistics distribution operations.

\section{Under the e-commerce environment logistics management innovation research}

\subsection{Innovation and improve the electronic commerce environment of logistics management system}

System innovation of the logistics management under the e-commerce environment, the need for a complete and perfect logistics management system, to network, professional and multi-functional logistics system construction and the combination of information construction, improve the management and efficiency of the logistics industry. Logistics management under the e-commerce environment mainly use logistics to logistics distribution information of a shift, so as to realize the mechanization and automation of the whole operation. Logistics management under the e-commerce environment need to accord with the requirement of modernization, with the characteristics of information. To make logistics enterprise development speed and convenient, more needs to be reasonably good use of logistics information network. Logistics management under the e-commerce environment can through the network, more of the system. The logistics management is not restricted by factors such as time and space, on the whole logistics system effectively.

\subsection{Invest more intelligent modern technology to logistics enterprise}

Under the e-commerce environment logistics management needs a new form of realization, intelligence is a trend of logistics management requires innovation. Therefore, logistics enterprises need to invest more in technology modernization, make logistics enterprise more intelligent. Technology support for intelligent to introduce foreign advanced technology, for our country's logistics management innovation to find a better direction, and provide effective technology to help 
the development of electronic commerce intelligence from the aspects of warehousing, distribution, logistics technology is analyzed, using the advanced management technology and the operation of the advanced technology, make the electronic commerce environment of logistics management. Through the in-depth study of expert system and intelligent system, in order to solve some of the logistics management, make the electronic commerce environment logistics management is to artificial intelligence.

\subsection{Cultivate innovative talents of logistics management, improve the innovation ability of logistics management}

To improve the innovation ability should be from the innovative talents of logistics management, fundamentally solve the problem of the innovation of the logistics management. Therefore practice the professional technology personnel training to logistics management. Logistics management under the e-commerce environment is very broad, mainly includes the theory of e-commerce, logistics theory, computer, database technology and enterprise management, etc., still need to make some marketing and psychology research innovative talents requires electronic information, economic management and other aspects of comprehensive ability, logistics industry also further strengthen staff quality, only good service consciousness, to promote the progress of the modern logistics management of logistics enterprises need is compound talents, can not only master the modern economic and trade information, and logistics operations, and access to the resources of the international trade for targeted training talents, the professional colleges and universities also need to pay more attention to, optimize classroom training education, make the innovation of the electronic commerce environment logistics management talent more autonomous learning ability and innovation ability, in order to achieve the requirement of logistics enterprises.

\subsection{The government shall in policy innovation, strengthen logistics industry support and guidance}

Logistics industry want to further development, also need the government to support and guide the government policy, make some innovation in practice, promote the development of logistics enterprises. First, the government should perfect the electronic commerce environment of logistics management rules and regulations. Government departments of the various functions and management need to have a clear goal, make logistics management more system and practices. Government guide to logistics enterprises also need some constructive mechanism, coordination of government departments, more diversified for logistics management, make the industry better and faster development and secondly, the government departments to take advantage of its coordination, scatter of the logistics industry has been changed, resulting in the effective management and guidance of logistics system, the logistics enterprises in the management of more coordination, more systematically, and the government department should also on transportation roads and communication information for logistics enterprises greater support in the end, the government should also help logistics enterprise innovation some basic conditions, to further improve the some infrastructure of logistics distribution. Government departments can take advantage of the city to form some model, make the small and medium-sized enterprise logistics management with good logistics system as soon as possible.

\section{Conclusion}

In spite of the current e-commerce environment, logistics management in our country still has a lot of problem to believe that the government attaches great importance to the relevant laws and regulations should be gradually improve. We promote the healthy and orderly development of logistics industry. In addition, the logistics industry should be under the guidance of logistics association, building strong industry internal regulations, strengthen the protection of innovation, encouraging innovation, punish irregularities and destruction of industry listed in article, accelerate the pace of developed countries, promote the electronic commerce environment logistics 
management innovation vigor, promote the sustainable development of the logistics goods and regions.

\section{References}

[1] GongXianJun. Logistics management in e-commerce environment of exploration [J]. Science and technology to become rich wizard, 2012-2012.

[2] Zhao Hao. Electronic commerce environment logistics management innovation [J]. Journal of electronic production, 2013-2013.

[3] Zheng Hengbin. Under the e-commerce environment logistics management innovation research [J]. Journal of logistics technology, 2012, 21:109-111.

[4] Li Deku. Electronic commerce environment logistics management innovation [J]. Circulation economy in China, 2013 preceding: 39-43.

[5] xiao-jie zhou. The electronic commerce environment of logistics management innovation research 